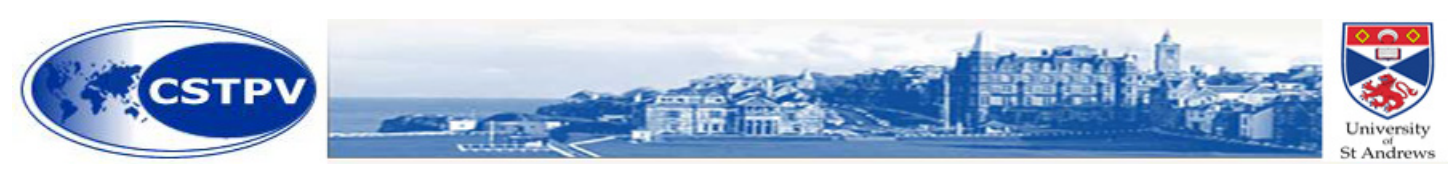

\title{
Listening to the Victims of Terrorism
}

\author{
Robert Lambert \\ Centre for the Study of Terrorism and Political Violence \\ University of St Andrews
}

When my grandfather retired from the Metropolitan Police in 1924 society paid little attention to the perspectives and needs of the victims of crime. This was as true for the victims of terrorism as for victims of other crimes. More recently the perspectives and interests of victims of crime in general and the victims of terrorism in particular have often assumed significant importance, not least in politics and in the media.

While I welcome this development I often find that the rich diversity of victims' perspectives is overlooked. That was certainly the case when politicians and journalists focused on the Lockerbie bombing victims' responses to the release from a Scottish prison and return to Libya of convicted Lockerbie bomber Abdelbaset Ali Mohmed al Megrahi. On 20 August 2009, Megrahi, suffering from cancer, was released on compassionate grounds by the Scottish Justice Secretary, Kenny MacAskill. Robert Mueller, director of the FBI, claimed the support of the Lockerbie bombing victims when he wrote a letter of trenchant complaint to MacKaskill:

....your action makes a mockery of the grief of the families who lost their own on December 21, 1988.... You could not have visited the small wooden warehouse where the personal items of those who perished were gathered for identification--the single sneaker belonging to a teenager; the Syracuse sweatshirt never again to be worn by a college student returning home for the holidays...

For the main part politicians and media pundits followed Mueller's line of argument but in doing so they overlooked the extent to which several Lockerbie victims took an entirely different view. For example Dr Jim Swire who lost his daughter Rosie in the bombing used the occasion to describe his ongoing concerns about the reliability of the evidence that led to al Megrahi's conviction. ${ }^{2}$ He expressed mixed reactions to al Magrahi's release: approval on the one hand because he believed in al Megrahi's innocence but disappointment as well that an appeal which he hoped would lead to justice had perforce been abandoned. ${ }^{3}$ Instead Swire, who worked with explosives as a Royal Engineer before becoming a GP, insisted that "the basic problem with the Lockerbie verdict", was "the complete discrediting of the principal identification witness in the trial, the Maltese shopkeeper Tony Gauci". 4

\footnotetext{
${ }^{1}$ The Independent, 2009. FBI director launches scathing attack on Kenny MacKaskill. 23 August. http://www.independent.co.uk/news/uk/home-news/fbi-director-launches-scathing-attack-on-kenny-macaskill-1776249.html accessed 11.1.11.

${ }^{2}$ Lockerbietruth.com http://www.lockerbietruth.com/ accessed 11.1.11.

${ }^{3}$ Lockerbietruth.com http://www.lockerbietruth.com/ accessed 11.1.11.

${ }^{4}$ Lockerbietruth.com http://www.lockerbietruth.com// accessed 11.1.11.
} 
Kevin McKenna is one journalist who defended MacAskill's decision and in doing so had recourse to the notion of 'dirty hands' - the sense of a greater political good arising from a moral choice that is known to be unpalatable:

MacAskill could have washed his hands of this issue and simply had a terminally ill man spend the few remaining days of his life in a Greenock prison cell. Few, beyond the masters of the British petroleum industry, would have demurred. ${ }^{5}$

With the benefit of hindsight we can see that al Magrahi has outlived MacAskill's expectations. For Mueller, the decision to release al Magrahi was wrong in any event, sending as it did the wrong signal to terrorists. However, as the death of Senator Edward Kennedy that same week reminded us, politicians on both sides the Atlantic have a history of being accused of 'appeasing terrorism'. Generally politicians will justify their actions in cases of this kind by reference to the 'dirty hands' doctrine where morally repugnant actions may be legitimated when they are understood to contribute to the greater good or eventual resolution of conflict. Suffice to say, Senator Kennedy was accused many times of appeasing IRA terrorists during the long process of conflict resolution.

McKaskill's decision and the real politik surrounding it raises its own 'dirty hands' dilemma for future policy decisions in this arena. Libya is no longer the terrorist threat to the West that it once was. As Edward Kennedy appreciated more than most the shift from conflict and terrorism to conflict resolution and peace cannot be achieved without politicians getting their hands dirty and causing hurt and anguish to the victims of terrorism, sometimes to the practitioners of counter-terrorism as well, in the process.

Once, however, Kennedy's influential role in brokering a deal with the IRA led to a ceasefire and a peace settlement his willingness to 'appease terrorists' was looked upon more favourably. In a penetrating obituary the novelist and commentator Joyce Carol Oates went further and described Edward Kennedy as a great politician who was allowed to atone for his part in the unresolved death of a junior political aide. ${ }^{6}$ This form of political redemption is not uncommon in Western democracies and demonstrates yet another aspect of the "dirty hands' phenomenon.

Naturally victims of terrorism and victims of crime generally are often the last people to appreciate the 'dirty hands' principle. That said, it is not uncommon for victims of terrorism to embrace projects that seek solutions and not punishment as a result of their experience. Carie Lemack is a good example, co-founder of Families of September 11, whose mother was killed that day at the world Trade Centre. Apart from working to ensure improvements in airport security Carie has also reached out to Muslim communities in the UK to explore opportunities to share her experience and to learn from it.

This lead to ground breaking work at the Brixton Mosque in London where al-Qaeda terrorists Richard Reid (the shoe bomber) and Zacarius Moussaoui (9/11 conspirator) once attended. Lemack's own account is compelling:

\footnotetext{
${ }^{5}$ McKenna, Kevin, 2009. http://www.guardian.co.uk/commentisfree/2009/aug/23/kenny-macaskill-decision-megrahi-release accessed 11.1.11.

${ }^{6}$ Oates, Joyce Carol, 2009. Kennedy's redemption from the depths. 27 August.

http://www.guardian.co.uk/world/2009/aug/27/edward-kennedy-usa accessed 11.1.11.
} 
I never thought I'd consider the chairman of the Brixton Mosque a close friend. A devout Muslim, Abdul Haqq Baker lives in Britain and Saudi Arabia with his wife, who chooses to wear a burqa, a garment that fully covers a woman's body, head and face. I am a proud American who chooses to wear tall leather boots and can't remember the last time I attended a religious service. Separately, we have each fought Al Qaeda extremists. Together, we both recognise that terrorists cannot be stopped until we move beyond stereotypes and ignorance, embrace our shared humanity and take away the one thing Al Qaeda and its affiliates exploit - passive support for their violent tactics. $^{7}$

Rather than focusing solely on the retributive nature of victims' responses to terrorism as Mueller does it is often more productive to promote and nurture reconciliation as an equally valid response to bereavement and loss.

\footnotetext{
${ }^{7}$ Lemack, 2008. Victims of terror unite. Common ground news service. 22 April http://www.commongroundnews.org/article.php?id=23012\&lan=en\&sid=1\&sp=0 accessed 11.1.11.
} 